\title{
Chronic pain, depression symptoms and daily living independency level among geriatrics in nursing home
}

\author{
Huzurevinde yaşayan geriatriklerin kronik ăgrı, depresyon semptomları \\ ve günlïk yaşamdaki bağımsızlık seviyesi
}

\author{
Ela TARAKCl, ${ }^{1}$ Yonca ZENGINLER, ${ }^{2}$ Ebru KAYA MUTLU³
}

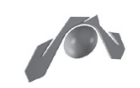

\begin{abstract}
Summary
Objectives: The aim of this study was to investigate pain, depression and independence in activities of daily living in geriatric residents of nursing homes, as well as to evaluate the relationship between these parameters.

Methods 186 nursing home residents, aged 65 to 90 years, were enrolled in the study. Their socio-demographic features, depression levels, pain levels and independence in activities of daily living were evaluated using a socio-demographic assessment form, the Geriatric Depression Scale (GDS), the Visual Analogue Scale (VAS) and the Nottingham Extended Activities of Daily Living Index (NEADL), respectively. For statistical analyses, participants were divided into groups with and without chronic pain.

Results: The main finding of this study was that $55.9 \%$ of the participants reported chronic pain, and these participants had significantly higher GDS $(p=0.001)$ and lower NEADL scores $(p=0.01)$ than those who reported no chronic pain. We found a significant correlation between VAS and GDS $(r=0.47, p=0.001)$, VAS and NEADL $(r=-0.30, p=0.001)$, and GDS and NEADL scores $(r=-0.50, p=0.001)$. Female gender $(p=0.001)$, number of children $(p=0.005)$, number of chronic diseases $(\mathrm{p}=0.009)$, and GDS score $(\mathrm{p}=0.001)$ were found to affect chronic pain in multivariate model.

Conclusion: Investigation of pain, presence of depression, and independence in activities of daily living is important in determining the necessary measures to be adopted for promoting the health and well-being of the geriatric population.
\end{abstract}

Key words: Activities of daily living; chronic pain; geriatrics; depression.

\section{Özet}

Amaç: Bu çalı̧madaki amacımız buzurevinde yaşayan geriatriklerin ağrı, depresyon, günlük yaşam aktivitelerindeki bağımsızlı̆̆ıı araştırmak ve bunun yanı sıra bu parametreler arasindaki ilişkiyi incelemekti.

Gereç ve Yöntem: Çalışmaya 65-90 yaş arası, buzurevinde yaşayan 186 gönüllü dabil edildi. Geriatriklerin sosyo-demografik özellikleri, depresyon seviyeleri, ağrı düzeyleri ve günlük yaşam aktivitelerinde bağımsızlikları sırasıyla sosyo-demografik değerlendirme formu, Geriatrik Depresyon Ölçeği (GDS), Görsel Analog Skala (VAS) ve Nottingham Extended Activities of Daily Living Index (NEADL), kullanılarak değerlendirildi. İstatistiksel analizler için, katılımcilar ağrısı olanlar ve olamayanlar olarak ayrıld.

Bulgular: Bu çalışmanın ana bulgusu, katılımcıların \%55.9'unun kronik ağrı bildirmesiydi ve bu bastaların anlamlı olarak daba yüksek GDS ( $p=0.001)$ ve kronik ağrısı olmayanlara göre anlamlı düzeyde düşük NEADL puanları $(p=0.01)$ vardı. Biz VAS ve GDS ( $r=0.47, p=0.001)$, VAS ve NEADL $(r=-0.30, p=0.001)$, GDS ve NEADL puanlari arasinda $(r=-0.50, p=0.001)$ önemli derecede korelasyon bulduk. Çok değişkenli modelde kadın cinsiyet $(p=0.001)$, çocuk sayısı $(p=0.005)$, kronik hastalık sayısı $(p=0.009)$ ve GDS skorunun ( $p=0.001)$ kronik ağrıyı etkilediği bulundu.

Sonuç: Geriatrik popülasyonda ağrı, depresyon varliğı ve günlük yaşam aktivitelerindeki bağımsızlık düzeylerinin incelenmesi, sağhlğın geliştirilmesinde ve yaşlı nüfusun refah için alınacak önlemlerin belirlenmesinde önemlidir.

Anahtar sözcükler: Günlük yaşam aktiviteleri; kronik ağrı; depresyon; geriatrikler.

\footnotetext{
'Department of Physiotherapy and Rehabilitation, Istanbul University Faculty of Health Sciences, Istanbul, Turkey; ${ }^{2}$ Department of Physiotherapy and Rehabilitation, Biruni University Faculty of Health Sciences, Istanbul, Turkey;

${ }^{3}$ Institute of Medical Sciences, Istanbul University, Istanbul, Turkey

'Isstanbul Üniversitesi, Sağlık Bilimleri Fakültesi, Fizyoterapi ve Rehabilitasyon Bölümü, İstanbul;

2Biruni Üniversitesi, Sağılk Bilimleri Fakültesi, Fizyoterapi ve Rehabilitasyon Bölümü, Istanbul;

${ }^{3}$ Istanbul Üniversitesi, Sağık Bilimleri Enstitüsü, İstanbul
}

Submitted (Başvuru tarihi) 18.12.2012 Accepted after revision (Düzeltme sonrası kabul tarihi) 14.05.2014

Correspondence (İletişim): Dr. Ela Tarakı. Demirkapı Caddesi, Karabal Sokak, Bakırköy Ruh ve Sinir Hastalıkları Hastanesi Bahçesi İçi, 34740 Bakırköy, İstanbul, Turkey.

Tel: +90 - 212 - 4141500 e-mail (e-posta): etarakci@istanbul.edu.tr 


\section{Introduction}

A longer life span and a decreasing birth rate results in demographic aging (defined as an increase in the percentage of the population aged 65 years or over), which is now an established trend in most regions of the world.

Pain is an unpleasant sensory and emotional experience, and is a multidimensional phenomenon with biological, psychological, social, and spiritual aspects. The elderly also suffer from functional disability. Consequently, they may become more dependent and inactive. ${ }^{[1]}$ According to the International Association for the Study of Pain, chronic pain is defined as "pain that persists beyond the normal tissue healing time, which is assumed to be 3 months" (IASP, 1986). Using this definition, estimates of the prevalence of chronic pain in elderly people $(\geq 60$ years) range from $28.9 \%$ to $59.3 \%$. $^{[2]}$

Clinically relevant depression is one of the most prevalent psychiatric conditions in later life, affecting up to $35 \%$ of the general population aged 60 years and older (with as high as $4 \%$ reporting a major depressive disorder as categorised by the Diagnostic and Statistical Manual of Mental Disorders, Fourth Edition). ${ }^{[3]}$ Because of its high prevalence and substantial ill effects, depression is a major contributor to the burden of illness in the geriatric population. Its effect on function, quality of life, and use of medical services is severe. The presence of depression in the elderly is associated with increased healthcare costs, worse outcomes after acute medical events such as hip fractures and stroke, decline in physical function, and poor survival.

Depression and chronic pain commonly occur together. Studies on severity of depression and secondary measures such as functional status, quality of life, health care costs and utilisation, and treatment efficacy have suggested that depression has a greater impact than other clinical factors on outcomes. Its effect on functional impairment in patients with pain. ${ }^{[4]}$ Berg et al. also reported that depression is associated with the severity of pain. ${ }^{[5]}$ Thus far, most depression and pain studies have either been crosssectional or have assessed the prognostic value of depression for poor pain outcomes.
It has been shown that common chronic diseases and loss of strength and coordination in the elderly make it difficult for them to independently perform activities of daily living. ${ }^{[6,7]}$ In addition, existing chronic pain and related depressive symptoms may cause these geriatrics to seek help in daily life activities. Therefore, our objective was to investigate pain, depression and independence levels in activities of daily living in geriatrics residing in nursing homes, and to evaluate the relationship between these parameters.

\section{Materials and Methods}

This cross-sectional descriptive observational study was carried out at nursing homes connected to social services. All participants gave written informed consent. The study was approved by the ethics committee. (Approval Date: 18.02.2011; Project No: 2011/386-454).

Nursing home residents aged $\geq 65$ years who were in a stable general health condition, had cognitive abilities sufficiently good for answering questions, and had been residing at the nursing home for at least 6 months were eligible for the study. Exclusion criteria included pain lasting $<3$ months, terminal illness, hearing impairment or dysphasia severe enough to prevent questionnaire completion, psychotic disease, or a cognitive disorder evidenced by a score of $\leq 23$ on the mini mental state examination (MMSE). ${ }^{[8]}$ A total of 186 nursing home residents (98 male, 88 female) fulfilled the inclusion criteria. Geriatrics were divided into two groups as chronic pain and no chronic pain group in our study.

We examined sociodemographic variables such as age, sex, marital status, educational level, and length of stay from file records in nursing homes and MMSE was performed by a physical therapist. The objectives of the study and the proposed methods were explained to the geriatrics. The surveys, which aimed at analysing pain, depression, and activities of daily living, were filled during a face-to-face interview with the participants who matched the inclusion criteria. Participant confidentiality was maintained.

Pain. The visual analogue scale (VAS) is one of the 
Table 1. Sociodemographic characteristics of geriatrics

\begin{tabular}{|c|c|c|c|c|c|c|c|c|}
\hline & \multicolumn{3}{|c|}{$\begin{array}{l}\text { Chronic pain } \\
(n=104)\end{array}$} & \multicolumn{3}{|c|}{$\begin{array}{l}\text { No chronic pain } \\
\quad(n=82)\end{array}$} & \multirow[b]{2}{*}{$x^{2}$} & \multirow[b]{2}{*}{$\mathbf{p}$} \\
\hline & $\mathbf{n}$ & $\%$ & Mean \pm SD & $\mathbf{n}$ & $\%$ & Mean \pm SD & & \\
\hline Age & & & $73.06 \pm 6.19$ & & & $72.72 \pm 6.65$ & & 0.72 \\
\hline \multicolumn{9}{|l|}{ Gender } \\
\hline Female & 64 & 61.5 & & 24 & 29.3 & & 0.00 & \\
\hline Male & 40 & 38.5 & & 58 & 70.7 & & & \\
\hline \multicolumn{9}{|l|}{ Marital status } \\
\hline Married & 16 & 15.4 & & 16 & 19.5 & & 0.02 & \\
\hline Single & 88 & 84.6 & & 66 & 80.5 & & & \\
\hline \multicolumn{9}{|l|}{ Education level } \\
\hline Nonliterate & 16 & 15.4 & & 8 & 9.8 & & 0.08 & \\
\hline Primary school & 69 & 66.3 & & 48 & 58.5 & & & \\
\hline High school or university & 19 & 18.3 & & 26 & 31.7 & & & \\
\hline VAS & & & $5.07 \pm 1.98$ & & & & & \\
\hline$(\min -\max )$ & & & $(1-8)$ & & & & & \\
\hline Length of stay in nursing home & & & $2.38 \pm 1.36$ & & & $2.18 \pm 0.99$ & & 0.24 \\
\hline Number of children & & & $2.71 \pm 1.12$ & & & $2.02 \pm 1.44$ & & 0.001 \\
\hline Number of chronic disease & & & $2.63 \pm 1.56$ & & & $1.83 \pm 1.63$ & & 0.001 \\
\hline
\end{tabular}

VAS: Visual anologue scale.

most frequently used instruments for assessing pain, both in research and in clinical practice. VAS consists of a $10-\mathrm{cm}$ line anchored by 2 extremes of pain, namely, no pain and extreme pain. Patients are asked to position a sliding vertical marker to indicate the level of pain they experience, and the pain severity is measured as the distance in $\mathrm{cm}$ between the 0 position and the marked spot. ${ }^{[9,10]}$ VAS is a more sensitive indicator of pain intensity than any other single-dimensional pain scale. In our study, a geriatric was coded as having chronic pain if they responded positively to the question 'Do you have a pain?', and meaningfully to the question 'How long have you had the pain?' Subsequently, we used VAS to assess the degree of pain. Otherwise, geriatrics were coded as having no chronic pain.

Depression. The most frequently used scale for measuring late-life depression is the geriatric depression scale (GDS). The GDS was originally developed as a 30-item questionnaire (GDS-30) in a simple yes/no response format. ${ }^{[1]}$ Sheikh et al. developed a shorter 15 -item form to improve the acceptability of the scale that used in our study. ${ }^{[12]}$ In the shorter form, scores above 5 represent depression with ascending severity. Scores of $0-4$ are considered normal, 5-8 indicate mild depression, 9-11 moderate depression, and $12-15$ indicate severe depression. This inventory was done reliability and validity Turkish by Ertan et al. ${ }^{[13]}$

Activities of Daily Living. The Nottingham extended activities of daily living (NEADL) is a physical disability scale that is valid and reliable in geriatrics with chronic diseases. ${ }^{[14]}$ It comprises 21 activities of daily living in the form of self-reported questions, and measures 4 domains: mobility (6 activities), kitchen (5 activities), domestic (4 activities), and leisure (6 activities). The overall scores range from 0 to 63 , with higher values indicating greater levels of independence. The reliability and validity of the Turkish version of the Nottingham Extended Activities of Daily Living Scale was done by Sahin et al. ${ }^{[15]}$

Statistical analysis was performed using SPSS 15.0 (SPSS Inc., Chicago, IL). The sample size was calculated by Raosoft, Inc. The original sample size estimate was fixed at 50 geriatrics to enable detection of a statistically significant difference between the chronic pain and no chronic pain groups at the 
Table 2. Comparison of the depression and daily living activities between chronic pain and no chronic pain group

\begin{tabular}{lccc}
\hline Parameters & Chronic pain $(\mathbf{n = 1 0 4 )}$ & No chronic pain $(\mathbf{n}=\mathbf{8 2})$ & p value \\
\cline { 2 - 3 } & Mean \pm SD & Mean \pm SD & \\
\hline GDS & $5.37 \pm 3.69$ & $3.51 \pm 2.27$ & 0.000 \\
NEADL & $39.85 \pm 20.51$ & $46.63 \pm 17.9$ & 0.01 \\
NEADL-Mobility & $11.92 \pm 6.52$ & $14.20 \pm 5.96$ & 0.01 \\
NEADL-Kitchen & $10.50 \pm 5.42$ & $11.78 \pm 4.97$ & 0.09 \\
NEADL-Domestic & $7.65 \pm 4.63$ & $8.71 \pm 4.02$ & 0.1 \\
NEADL-Leisure & $9.77 \pm 5.88$ & $12 \pm 5.4$ & 0.01 \\
\hline
\end{tabular}

GDS: Geriatric depression scale; NEADL: Nottingham extanded activities of daily index.

$10 \%$ level with a power of $90 \%$ within the trial. The data were tested for normal distribution by using the Shapiro-Wilk test. Our data was found normally distributed so that parametric test was used for statistical analysis. All variables were expressed as arithmetic mean \pm standard deviation $(\mathrm{X} \pm \mathrm{SD})$ values. The assessment data between the 2 groups were compared using the independent sample t test, and categorical variables were compared using Chisquare analysis. Correlations between parameters were examined through Pearson's correlation analysis. A correlation coefficient of 0.26 to 0.49 reflects poor, 0.50 to 0.69 reflects moderate, and $\geq 0.70$ reflects high correlation. Next, linear regression analysis was used to determine predictors of chronic pain. Independent variables entered into the regression analysis included gender, number of children, number of chronic diseases, presence of monthly income, marital status, and education level. Statistical significance was set at $\mathrm{p}<0.05$.

\section{Results}

The study included 186 volunteers aged 65 to 90 years and living in nursing homes. Table 1 lists the sociodemographic characteristics of the study population. The chronic pain group consisted of 104 sub- jects (40 men and 64 women; mean age, $73.06 \pm 6.19$ years) and the group with no chronic pain consisted of 82 subjects ( 58 men and 24 women; mean age, $72.72 \pm 6.65$ years). There were no significant differences in the age, educational level and length of stay in nursing home and significant differences in gender, marital status, the number of children and number of chronic diseases in the two groups.

Table 2 compares the levels of depression and independence in activities of daily living between the two groups. GDS scores were significantly higher $(\mathrm{p}=0.001)$, and NEADL total scores were significantly lower $(\mathrm{p}=0.01)$ in the chronic pain group. Additionally, the chronic pain group had significantly lower scores in the NEADL mobility and leisure domains $(\mathrm{p}=0.01)$. There were no statistically significant differences in other outcome measures.

The relationship between VAS, GDS, NEADL, and age in the chronic pain group is represented in Table 3. Significant correlation was found between VAS and GDS ( $\mathrm{r}=0.47, \mathrm{p}=0.001)$, VAS and NEADL $(\mathrm{r}=-0.30, \mathrm{p}=0.001)$, GDS and NEADL $(\mathrm{r}=-0.50$, $\mathrm{p}=0.001)$, and GDS and age $(\mathrm{r}=0.16, \mathrm{p}=0.02)$. No significant correlation was found between VAS and age $(\mathrm{r}=0.08, \mathrm{p}=0.23)$.

Table 3. The relationship between depression, pain and NEADL

\begin{tabular}{|c|c|c|c|}
\hline & VAS & GDS & AGE \\
\hline Geriatric depression scale & $r=0.47 p=0.01$ & & \\
\hline AGE & $r=0.08 p=0.23$ & $r=0.16 p=0.02$ & \\
\hline Nottingham extanded activities of daily index & $r=-0.30 p=0.01$ & $r=-0.50 p=0.01$ & $r=-0.25 p=0.01$ \\
\hline
\end{tabular}

VAS: Visual anologue scale; GDS: Geriatric depression scale; NEADL: Nottingham extanded activities of daily index. 
Table 4. Clinical variables used in linear regression analysis to predict chronic pain in geriatrics

\begin{tabular}{|c|c|c|c|c|c|c|c|}
\hline \multirow[t]{2}{*}{ Variable } & \multicolumn{2}{|c|}{$\begin{array}{l}\text { Unstandardized } \\
\text { coefficents }\end{array}$} & \multirow{2}{*}{$\begin{array}{c}\begin{array}{c}\text { Standardized } \\
\text { coefficents }\end{array} \\
\text { Beta }\end{array}$} & \multicolumn{2}{|c|}{$\begin{array}{c}\mathbf{9 5 \%} \text { Confidence } \\
\text { intervals }\end{array}$} & \multirow[t]{2}{*}{$\mathbf{t}$} & \multirow[t]{2}{*}{ p value } \\
\hline & B & SD & & Lower & Upper & & \\
\hline Gender & -1.57 & 0.38 & -0.27 & -2.34 & -0.81 & -4.09 & 0.000 \\
\hline Number of children & 0.40 & 0.14 & 0.18 & 0.126 & 0.67 & 2.87 & 0.005 \\
\hline Number of chronic disease & 0.29 & 0.11 & 0.16 & 0.07 & 0.51 & 2.65 & 0.009 \\
\hline Marital status & -0.61 & 0.47 & -0.07 & -1.54 & 0.31 & -1.29 & 0.19 \\
\hline Education level & 0.26 & 0.31 & 0.05 & -0.36 & 0.89 & 0.83 & 0.40 \\
\hline NEADL & -0.01 & 0.01 & -0.12 & -0.03 & 0.00 & -1.17 & 0.07 \\
\hline GDS & 0.29 & 0.06 & 0.32 & 0.16 & 0.42 & 4.44 & 0.000 \\
\hline
\end{tabular}

NEADL: Nottingham extanded activities of daily index; GDS: Geriatric depression scale.

Table 4 details the outcome of the linear regression analysis. Several variables were associated with chronic pain in the multivariate model, including female sex $(\mathrm{p}=0.001)$, number of children $(\mathrm{p}=0.005)$, number of chronic illnesses $(\mathrm{p}=0.009)$, and GDS score $(\mathrm{p}=0.001)$. Marital status $(\mathrm{p}=0.19)$, education level $(\mathrm{p}=0.40)$, and NEADL $(\mathrm{p}=0.07)$ were not correlated with chronic pain.

\section{Discussion}

To our knowledge, pain is a common symptom among geriatric residents in nursing homes and can have adverse effects on depression symptoms and activities of daily living. The main finding of this study is that $>50 \%$ of the geriatric population in nursing homes reported chronic pain, which is in concurrence with previous reports. ${ }^{[16,17]}$

Our results showed that pain severity and intensity increase with increasing age. Similarly, Leong et al., and Brochet et al. reported that residents with chronic pain were older than those without pain. ${ }^{[18,19]}$ Other studies have failed to find a significant association between pain and the residents' age..$^{[2,20]}$ A possible explanation for this discrepancy is that nursing home residents often consider pain to be a part of the aging process, and thus may not always report pain to their caregivers. Our results also showed that the number of chronic diseases as well as gender affect pain. Several studies have investigated the relationship between pain and number of chronic diseases. ${ }^{[20,21]}$ Smalbrugge et al., and Sawyer et al. have also shown that female residents are more likely to report pain. ${ }^{[22,23]}$

Depression has been reported to be a common problem in the geriatric population living in nursing homes, and has been shown to be associated with chronic pain. ${ }^{[5,24-26]}$ Bair et al. demonstrated that moderate to severe pain was associated with more depressive symptoms and worse depression outcomes. ${ }^{[24]}$ A study by Ohayon et al. also showed chronic pain was associated with a higher severity of depression, longer episode duration, and a greater likelihood of certain depressive symptoms. ${ }^{\text {[27] }}$ Baker et al. found a direct and significant relationship between pain and depressive symptoms. ${ }^{[25]}$ In another study, Smalbrugge et al. showed a correlation between pain, anxiety, and depression in geriatric patients. ${ }^{[22]}$ Depression was also shown to be associated with the severity of pain. ${ }^{[5]}$ In contrast, Iliffe et al. reported that pain frequency and severity were not significantly associated with a depressive mood. ${ }^{[28]}$ In the current study, depression was significantly related to pain, and conversely, the elderly with chronic pain had depression symptoms. Our results showed that depression is an important factor affecting pain, and thus should be adequately addressed in the geriatric population.

Aging is associated with a significant dependency in activities of daily living. The link between pain and decreased activities of daily living has often been noted, but there is little data on the direct relationship between pain prevalence and activities of daily living. The inability to perform activities of daily living has a negative impact on the lives of the elderly. Higher 
pain intensity leads to greater limitations in activities of daily living, ${ }^{[29]}$ and conversely, residents who are dependent in their activities of daily living are more likely to suffer from excruciating pain. ${ }^{[21]}$ Takai et al. reported that pain commonly occurs in the legs and lower back, and can lead to a decrease in activities of daily living. ${ }^{[30]}$ Pain has also been shown to affect recreational activities, social events, ambulation, and posture. ${ }^{[31]}$ In our study, the chronic pain group had significantly lower scores in the activities of daily living, particularly in the mobility and leisure domains of NEADL. This may be due to pain, which affects the function of the lower extremities to a greater extent, as noted in other studies. The kitchen and domestic domains of NEADL were not affected by pain, possibly because despite the pain, the elderly need to resume these activities of daily living.

Depression is an important factor affecting the activities of daily living. Changes in cognitive processes due to aging lead to difficulties in comprehension, perception, coordination, and also weakening or loss of the senses. The associated difficulty in living as an able, active, and independent person may affect their mental well-being. An important finding of our research is the correlation between an increase in depression and dependency in activities of daily living. Our results are in accordance with those of Kaup et al., who reported that the rate of depression increased with more dependence in activities of daily living. ${ }^{[32]}$ Drageset et al. also reported that depression significantly affected activities of daily living. [7] Several studies have also shown that depressive geriatric patients are more likely to be dependent in basic activities of daily living. ${ }^{[33,34]}$

There are several limitations to this study. First, our subjects were restricted to nursing home residents, and this sample may not be representative of the general geriatric population. Second, outcome measures were based on self-reported data, in which the pain intensity measured was based on subjective perception, and the cause of pain was not contingent on a particular progressive or traumatic disease or onset. Nevertheless, the self-report measures used in this study are appropriate for the constructs examined and are well developed with established discriminate validity. Although these factors alone are not sufficient for establishing their validity for a particular population, it indicates that the items were internally consistent, and supports their use for our study purpose.

The main finding of this study is that $>50 \%$ of the geriatric population in nursing homes reported chronic pain. Depression levels were higher and there was greater dependency in activities of daily living in the chronic pain group than in the group without chronic pain. We also found a correlation between chronic pain and depression, female gender, number of children, and number of chronic diseases. Chronic pain was also associated with dependency in certain activities of daily living. In view of the results, we suggest that in order to increase the level of independence in the geriatric population, all factors affecting pain should be considered.

\section{Acknowledgements}

The authors wish to thank Prof. Nurhan Ince,MD for her kind helps in the statistical analysis. We are also grateful to all the elderly who participated in this study. We would like to thank Barış Cavlak, PT for his helps in the nursing homes.

\section{Conflict-of-interest issues regarding the author- ship or article: None declared.}

\section{Peer-rewiew: Externally peer-reviewed.}

\section{References}

1. Reid MC, Williams CS, Gill TM. Back pain and decline in lower extremity physical function among community-dwelling older persons. J Gerontol A Biol Sci Med Sci 2005;60(6):793-7.

2. McCarthy LH, Bigal ME, Katz M, Derby C, Lipton RB. Chronic pain and obesity in elderly people: results from the Einstein aging study. J Am Geriatr Soc 2009;57(1):115-9.

3. Steffens DC, Skoog I, Norton MC, Hart AD, Tschanz JT, Plassman $\mathrm{BL}$, et al. Prevalence of depression and its treatment in an elderly population: the Cache County study. Arch Gen Psychiatry 2000;57(6):601-7. CrossRef

4. Linton SJ. A review of psychological risk factors in back and neck pain. Spine 2000;25(9):1148-56. CrossRef

5. Bergh I, Steen G, Waern M, Johansson B, Odén A, Sjöström B, et al. Pain and its relation to cognitive function and depressive symptoms: a Swedish population study of 70-year-old men and women. J Pain Symptom Manage 2003;26(4):90312. CrossRef

6. Brach JS, VanSwearingen JM. Physical impairment and disability: relationship to performance of activities of daily living in community-dwelling older men. Phys Ther 2002;82(8):752-61.

7. Drageset J, Eide GE, Ranhoff AH. Depression is associated 
with poor functioning in activities of daily living among nursing home residents without cognitive impairment. J Clin Nurs 2011;20(21-22):3111-8.

8. Folstein MF, Folstein SE, McHugh PR. "Mini-mental state". A practical method for grading the cognitive state of patients for the clinician. J Psychiatr Res 1975;12(3):189-98. CrossRef

9. Price DD, McGrath PA, Rafii A, Buckingham B. The validation of visual analogue scales as ratio scale measures for chronic and experimental pain. Pain 1983;17(1):45-56. CrossRef

10. Tiplady B, Jackson SH, Maskrey VM, Swift CG. Validity and sensitivity of visual analogue scales in young and older healthy subjects. Age Ageing 1998;27(1):63-6. CrossRef

11. Yesavage JA, Brink TL, Rose TL, Lum O, Huang V, Adey M, et al. Development and validation of a geriatric depression screening scale: a preliminary report. J Psychiatr Res 19821983;17(1):37-49.

12. Sheikh JI, Yesavage JA. Geriatric depression scale: recent evidence and development of a shorter version. Clin Gerontol 1986;5:165-73. CrossRef

13. Ertan T, Eker E, Şar V. Geriatrik depresyon ölçeğinin Türk yaşlı nüfusunda geçerlilik ve güvenirliği. Nöropsikiyatri Arşivi 1997;34:62-71.

14. Nouri FM, Lincoln NB. An extended activities of daily living scale for stroke patients. Clin Rehab 1987;1:301-5. CrossRef

15. Sahin F, Yilmaz F, Ozmaden A, Kotevoglu N, Sahin T, Kuran B. Reliability and validity of the Turkish version of the Nottingham Extended Activities of Daily Living Scale. Aging Clin Exp Res 2008;20(5):400-5. CrossRef

16. Jakobsson U, Klevsgård R, Westergren A, Hallberg IR. Old people in pain: a comparative study. J Pain Symptom Manage 2003;26(1):625-36. CrossRef

17. Miró J, Paredes S, Rull M, Queral R, Miralles R, Nieto R, et al. Pain in older adults: a prevalence study in the Mediterranean region of Catalonia. Eur J Pain 2007;11(1):83-92. CrossRef

18. Leong IY, Nuo TH. Prevalence of pain in nursing home residents with different cognitive and communicative abilities. Clin J Pain 2007;23(2):119-27. CrossRef

19. Brochet B, Michel P, Barberger-Gateau P, Dartigues JF. Population-based study of pain in elderly people: a descriptive survey. Age Ageing 1998;27:279-84. CrossRef

20. Torvik K, Kaasa S, Kirkevold $\varnothing$, Rustøen T. Pain in patients living in Norwegian nursing homes. Palliat Med 2009;23(1):8-16.

21. Teno JM, Kabumoto G, Wetle T, Roy J, Mor V. Daily pain that was excruciating at some time in the previous week: prevalence, characteristics, and outcomes in nursing home residents. J Am Geriatr Soc 2004;52(5):762-7. CrossRef
22. Smalbrugge $M$, Jongenelis LK, Pot AM, Beekman AT, Eefsting JA. Pain among nursing home patients in the Netherlands: prevalence, course, clinical correlates, recognition and analgesic treatment--an observational cohort study. BMC Geriatr 2007;7:3. CrossRef

23. Sawyer P, Lillis JP, Bodner EV, Allman RM. Substantial daily pain among nursing home residents. J Am Med Dir Assoc 2007;8(3):158-65. CrossRef

24. Bair MJ, Robinson RL, Katon W, Kroenke K. Depression and pain comorbidity: a literature review. Arch Intern Med 2003;163(20):2433-45. CrossRef

25. Baker TA, Buchanan NT, Small BJ, Hines RD, Whitfield KE. Identifying the relationship between chronic pain, depression, and life satisfaction in older African Americans. Res Aging 2011;33:426-43. CrossRef

26. Meeks TW, Dunn LB, Kim DS, Golshan S, Sewell DD, Atkinson $\mathrm{JH}$, et al. Chronic pain and depression among geriatric psychiatry inpatients. Int J Geriatr Psychiatry 2008;23(6):637-42.

27. Ohayon MM, Schatzberg AF. Using chronic pain to predict depressive morbidity in the general population. Arch Gen Psychiatry 2003;60(1):39-47. CrossRef

28. Iliffe S, Kharicha K, Carmaciu C, Harari D, Swift C, Gillman G, et al. The relationship between pain intensity and severity and depression in older people: exploratory study. BMC Fam Pract 2009;10:54. CrossRef

29. Cadogan MP, Edelen MO, Lorenz KA, Jones M, Yosef J, Hascall $\mathrm{T}$, et al. The relationship of reported pain severity to perceived effect on function of nursing home residents. $J$ Gerontol A Biol Sci Med Sci 2008;63(9):969-73. CrossRef

30. Takai Y, Yamamoto-Mitani N, Okamoto Y, Koyama K, Honda A. Literature review of pain prevalence among older residents of nursing homes. Pain Manag Nurs 2010;11(4):209-23. CrossRef

31. Ferrell BA, Ferrell BR, Osterweil D. Pain in the nursing home. J Am Geriatr Soc 1990;38(4):409-14.

32. Kaup BA, Loreck $D$, Gruber-Baldini AL, German $P$, Menon AS, Zimmerman $S$, et al. Depression and its relationship to function and medical status, by dementia status, in nursing home admissions. Am J Geriatr Psychiatry 2007;15(5):438-42.

33. Civi S, Tanrikulu MZ. An epidemiological study to evaluate the level of dependence and physical disability with the prevalance of chronic diseases in the elderly. Turk J Geriatrics 2000;3(3):85-90.

34. Covinsky KE, Fortinsky RH, Palmer RM, Kresevic DM, Landefeld CS. Relation between symptoms of depression and health status outcomes in acutely ill hospitalized older persons. Ann Intern Med 1997;126(6):417-25. CrossRef 